\title{
Strategy Model for Increasing the Potential of Zakat through the Crowdfunding- Zakat System to overcome Poverty in Indonesia
}

\author{
Ajeng Sonial Manara \\ Airlangga University \\ Arif Rachman Eka Permata and R. Gatot Heru Pranjoto \\ Trunojoyo Madura University
}

\begin{abstract}
In Indonesia, through Presidential Regulation No. 18 of 2007, Indonesia's annual economic development goals are directed to encourage economic growth in order to expand employment and reduce poverty. With implications for income equity, zakat has a strategic potential that is feasible to be developed into one of the instruments of income distribution in Indonesia. Based on data collection and distribution of funds of the Zakat Management Organization below, in 2015, the total fund collection experienced a growth of $10.62 \%$ compared to 2014. This study will discuss discussing the related Strategy Model for Increasing the Potential of Zakat through Crowdfunding-Zakat System for poverty alleviation in Indonesia. Abdullah (2015) in his research developed a new methodology to measure poverty alleviation in Pakistan, focusing on consumption / expenditure of poor households for basic needs, government expenditure in terms of zakat and the number of recipients of zakat as the three main determinants. In Syafiq (2014) the realization of the prospect of zakat in the modern economy must also be supported by the management of zakat management organizations in a modern way, meaning that in the fundraising strategy, and the distribution must follow modern management and strategy as a company in achieving its target. Thaker and Pitchay (2018) through their research revealed that crowdfunding model is used to raise funds to develop Waqf land in Malaysia where in their research they propose a sustainable model that can overcome liquidity problems faced by Waqf institutions in developing Waqf land. Using qualitative research methods with a literature study approach. With the crowdfinding-zakat system, it provides convenience in the collection of zakat funds from the wider community in line with several regions in Indonesia that show the potential and positive impact on income distribution.
\end{abstract}

Keywords: zakat, crowdfunding-zakat system, poverty.

\section{INTRODUCTION}

Poverty is still a fundamental problem faced by the Indonesian people (Azhar, et. al .:2017, 16). The causes of poverty can be seen from several existing social conditions. Based on Kakwani in Ahmed, et. al. (2017) are seen as poor people not only in material seizures (measured by income or consumption) but also in different aspects of life such as unemployment, poor health, lack of education, vulnerability, powerlessness or social exclusion. So that in Indonesia, through Presidential Regulation No. 18 of 2007, Indonesia's annual economic development goals are directed to encourage economic growth in order to expand employment and reduce poverty (Fathurrahman, 2012). Therefore, the government policy then accompanies the operational existence of the zakat 
institution. The government passed laws to establish zakat institutions or give approval to organizations to manage the collection and distribution of zakat, it is very likely that Muslims see the law or agreement as a sign of legitimacy to operate (Mustafa, et. al., 2013). The implications for income distribution are where zakat is the main role. Zakat has strategic potential that is feasible to be developed as one of the instruments of income distribution in Indonesia (Thalib, et. al., 2017). Based on data collected and disbursed by the Zakat Management Organization below, the collection of zakat funds at the National level experienced a significant increase from 2010 to 2015 .

Table 1. Growth of Zakat Fund Collection in 20102015 Nationally and in each Zakat Management Organization

\begin{tabular}{|c|c|c|c|c|c|c|}
\hline year & BAZNAS & $\begin{array}{c}\text { BAZNAS in } \\
\text { Province }\end{array}$ & $\begin{array}{c}\text { BAZNAS in } \\
\text { district/ City }\end{array}$ & LAZ & National & Growth \\
\hline 2010 & 33.125 .920 .074 & 306.512 .258 .082 & 525.608 .580 .693 & 634.917 .482 .126 & 1.500 .164 .240 .975 & \\
\hline 2011 & 40.403 .967 .865 & 204.482 .157 .749 & 824.014 .964 .426 & 659.963 .269 .358 & 1.728 .864 .359 .398 & $15,25 \%$ \\
\hline 2012 & 50.212 .435 .875 & 253.252 .821 .346 & 1.179 .716 .104 .080 & 729.217 .590 .043 & 2.212 .398 .951 .344 & $27,97 \%$ \\
\hline 2013 & 59.238 .304 .066 & 1.645 .482 .867 .203 & 281.687 .974 .612 & 653.194 .923 .848 & 2.639 .604 .069 .729 & $19,31 \%$ \\
\hline 2014 & 82.293 .545 .780 & 415.451 .020 .092 & 1.422 .364 .285 .476 & 1.379 .891 .148 .652 & 3.300 .000 .000 .000 & $25,02 \%$ \\
\hline 2015 & 94.068 .893 .820 & 642.797 .514 .841 & 885.309 .169 .850 & 2.028 .193 .434 .453 & 3.650 .369 .012 .964 & $10,62 \%$ \\
\hline
\end{tabular}

Source: BAZNAS (2017: 11).

With the allocation of zakat collection it also contributes to the empowerment of the poor. Based on Berita Resmi Statistik No. 05/01/Th. XXI, 2 Januari 2018, if we look at the last ten years, the number of poor people has gradually fluctuated. In 2007 to 2013, the poor population decreased from $16.58 \%$ in 2007 , $15.42 \%$ in $2008,14.15 \%$ in $2009,13.33 \%$ in $2010,12.49 \%$ in March 2011, $12.36 \%$ in September 2011, 11.96\% in March 2012, $11.66 \%$ in September 2012, $11.36 \%$ in March 2013, and $11.46 \%$ in September 2013 of the total population. Whereas in 2014 towards 2017, the number of poor people experienced not too significant fluctuations, from $11.25 \%$ in March 2014, $10.96 \%$ in September 2014, $11.22 \%$ in
March 2015, 11.13\% in September 2015, $10.86 \%$ in March 2016, $10.70 \%$ in September 2016, 10.64\% in March 2017, and $10.12 \%$ in September 2017. The percentage results show that the government has so far played an active role in reducing poverty. This is a form of the implementation of government programs in line with the role of other funding sources that are used as poverty alleviation. Through providing employment and capital to them, in addition to poverty, people will have a source of income from their own productivity.

Graph 1. Number of Poor People

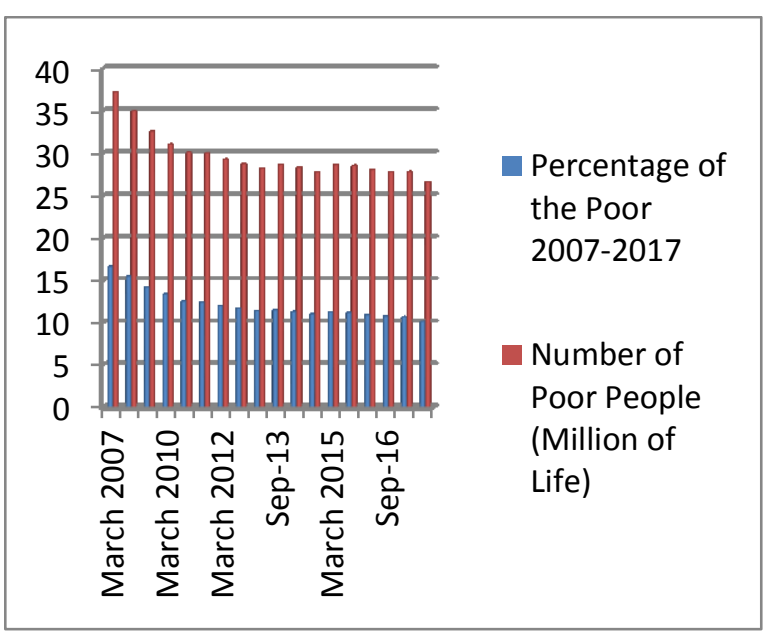

Source: Berita Resmi Statistik No. 05/01/Th. XXI, 2 Januari 2018 has been processed.

This increase is in line with the increase in the number of people and residents who are obliged to pay tithe (sophisticated, et. al., 2017). Given the growth in zakat collection, at present the community is faced with the need for efficiency in channeling the zakat. Along with the rapid development of technology, the matter of giving zakat can now also be done through the internet. The alternative funding is known as crowdfunding. Crowdfunding is a funding scheme that collects funds from internet-based crowd (Arifin and Wisudanto, 2017). Based on research from Thaker and Pitchay (2018) Crowfunding model is used to raise funds to develop Waqf land in Malaysia where in their research they propose a sustainable 
model that can overcome liquidity problems faced by Waqf institutions in developing Waqf land. In Indonesia, there are four official zakat distribution sites in the country including Dompet Dhuafa, Rumah Zakat, National Zakat Agency/ Badan Amil Zakat Nasional (BAZNAS), and Kitabisa.com. Based on the discussion above, this research will discuss discussing the Strategy for Increasing the Potential of Zakat through the Crowdfunding-Zakat System in alleviating poverty in Indonesia.

\section{LITERATURE REVIEW}

\section{The purpose of Zakat}

Zakat is one of the pillars of Islam which has a social dimension. That is, the implementation of zakat is not just to abort the obligation as a Muslim, but it is hoped that it will be able to contribute solutions to social problems, especially poverty (Tim Divisi Kepatuhan dan Kajian Dampak LAZ al-Azhar, 2017: 4). In the concept of Islam, zakat is one of the state's revenues. Therefore, the acquisition of zakat is very important for the survival of the life of the state to achieve common goals, prosperity (Azhar, 2017: 91). Zakat is one of the pillars of Islam with a dimension of social justice (Andriyanto, 2014). The essence of zakat is the management of funds taken from aghniyā '(Surah al-Taubah [9]: 103) to be submitted to those who are entitled to receive it (Surah al-Taubah [9]: 60) and aims to prosper the social life of Muslims (Surat al-Dzariyat [51]: 19).

To run the wheels of government, it must be based on the values of equality of justice which includes economic activities and distribution. The principle of economic distribution that becomes a guideline in the Islamic economic system is to increase production (output), and distribution of wealth so that the circulation of wealth increases and allows bringing fair distribution among various components of society, and does not focus capital on a small portion of certain groups (Hidayat, 2017). In the Islamic macroeconomic model with an expenditure approach, the domestic economy does not only consist of three sectors, namely individuals, business and government but there is also a social sector. This sector includes social institutions in the community, including foundations, amil zakat, orphanages, nongovernmental organizations and so on $(\mathrm{K}$. Amiruddin, 2015).

Therefore zakat management organizations are required not only to be trustworthy and professional zakat managers, but also to be able to bring benefit in the midst of the people through comprehensive and real zakat empowerment programs providing solutions for the welfare of the community and overcoming poverty (Tim Divisi Kepatuhan dan Kajian Dampak LAZ alAzhar, 2017: 4): This is confirmed in Law No. 23 of 2011 concerning Zakat Management Article 3, namely: Zakat Management aims to improve the effectiveness and efficiency of services in the management of zakat; and increasing the benefits of zakat to realize community welfare and poverty alleviation.

Various instruments that can be used as sources of state financing are basically muamalah aspects, in this case not including zakat (P3EI, 2014: 511). Qaradhawi's view is included in what can be called an "orthodox" school that treats zakat as a form of devotional law (worship). Therefore, the form and details of the rules must remain intact as revealed. However, contemporary Islamic economists, like, Khan argues that zakat should be classified as transactional law and not a law of piety (Obaidullah, 2016). In Islamic public finance, zakat is one of the financial instruments used for public spending as part of the source of government opinion issued to meet the needs of the intertwined people included in the 8 mustahiq groups (Jaelani, 2015). This characteristic makes zakat inherently has several properties including:

a. Pro-poor and self-integrated. 
b. Zakat has clear provisions with a certain measure of expenditure and time that cannot be changed by anyone.

c. Zakat has different terms of expenditure for different types of property.

d. Zakat has a broad target base for all economic activities.

e. Zakat is a spiritual tax that must be issued by the Muslim community under any conditions (Azhar, 2017: 19).

\section{Crowdfunding-Model}

Given the growth in zakat collection, at present the community is faced with the need for efficiency in channeling the zakat. Along with the rapid development of technology, the matter of giving zakat can now also be done through the internet. The alternative funding is known as crowdfunding. Valanciene \& Jegeleviciute (2014) define crowdfunding as a method for connecting between entrepreneurs who want an increase in capital and new investors who have capital resources and want to invest in small amounts through internet-based intermediary entities. Lambert and Schwienbacher in Thaker and Anwar (2018) have defined crowdfunding as "open calls, basically through the internet, to provide financial resources in the form of donations or in exchange for some form of rewards and / or voting rights to support initiatives for specific purposes".

Figure 1. Crowdfunding platform

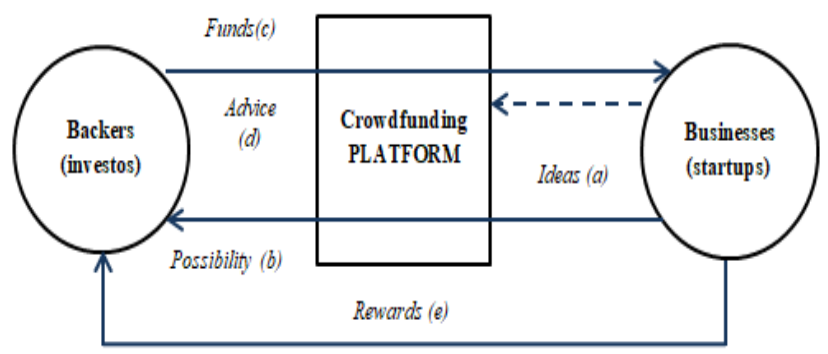

Source: Valancienen \& Jegeleviciute, 2014.

There are three main parties who become stakeholders, namely entrepreneurs, crowdfunding platforms, and investors (backers). The main stakeholders have their respective roles and interests. The first path starts from entrepreneurs (business or startups) submitting ideas, funding requests through crowdfunding platforms and promising returns to investors. Backers (investors) will look at the investment opportunities offered by entrepreneurs and give their commitment to funding or giving advice. The crowdfunding platform acts as an intermediary institution that brings together investors and backers (Valanciene \& Jegeleviciute, 2014). The legal basis of crowdfunding is helping each other in kindness / takaful and free of usury. So far, what is funded in crowdfunding is a social project, such as raising the economy of small communities and solving poverty. This has been explained in paragraph Q.S. al-Maidah: 2 which reads:

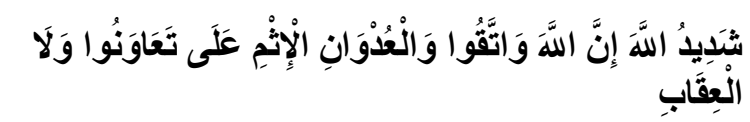

Meaning:

"And do not help in committing sins and transgressions. And fear Allah, for verily Allah is severe in His punishment." (Surat al-Maidah: 2).

Crowdfunding can be divided into four categories: crowdfunding donations, crowdfunding prizes, crowdfunding loans, and equity crowdfunding. Including the following:

\section{a. Crowdunding Donations}

Crowfunding donations / donations are places where funds are collected for social, artistic, philanthropic or other purposes, and not as a reward for something of real value. It does not provide material returns (Massolution in Thaker and Anwar, 2018). For example, in the US, Kickstarter, Indiegogo and others are one platform that supports crowdfunding-based donations. In Indonesia, there are several crowdfunding platforms including Dompet Dhuafa, Rumah 
Zakat, National Zakat Agency (BAZNAS), and Kitabisa.com.

b. Crowdunding Rewards

Crowfunding reward is a collection of funds, where investors or donors receive some real prizes (such as membership gift schemes, products, coupons and others) as appreciation tokens. This award can be in various forms and not in the form of money (cash) (Massolution in Thaker and Anwar, 2018). For example Kicktstarter, Rockethub, Indiegogo and others.

\section{c. Lend Crowdfunding}

Lending crowdfunding is an online platform that matches lenders or investors with borrowers or issuers to provide loans at low interest rates set by the platform (Massolution in Thaker and Anwar, 2018). There are several platforms regulating loans between individuals, while other platforms raise funds and then lend to small and medium enterprises. Some prominent examples from the US are Lending Club, Prosper, and others. and from England is Zopa, Funding Circle, etc. Some platforms charge fees based on loans.

d. Equity-based Crowdfunding

Equity-based crowdfunding refers to funds collected through online by a business, especially early-stage funding, by offering investors equity interests in business (Massolution in Thaker and Anwar, 2018). Businesses seeking to raise capital through this mode usually advertise online through crowdfunding platform websites, which function as intermediaries between investors and start-up companies (Massolution in Thaker and Anwar, 2018). In the UK two platforms, Crowdcube and Seedrs, have dominated the narrative for crowdfunding investment in terms of equity.
Some of the previous studies that became the reference in this study were according to According to Fathurrahman (2012), poverty is not only related to cultural problems, but also structural problems concerning how the state makes fiscal policies oriented to poverty alleviation culturally, Islam advocates the role of every individuals in improving their quality of life and fostering a process of social togetherness through zakat, infaq, and sadaqah. In Jalles (2017), fiscal adjustments are explained, according to their nature, affecting income inequality. Hidayat (2017) revealed that one of the impacts of income inequality is the increasing capital of capital owners. The owner of the capital becomes even richer because of the profits earned, while the worker only has the capital of his labor and expertise.

In K. Amiruddin (2015) explained that the concept of zakat in Islam is the elements contained in fiscal policy. Abdullah (2015) in his research developed a new methodology to measure poverty alleviation in Pakistan, focusing on consumption / expenditure of poor households for basic needs, government expenditure in terms of zakat and the number of recipients of zakat as the three main determinants. In Syafiq (2014) the realization of the prospect of zakat in the modern economy must also be supported by the management of zakat management organizations in a modern way, meaning that in the fundraising strategy, and the distribution must follow modern management and strategy as a company in achieving its target. Thaker and Pitchay (2018) through their research revealed that crowdfunding model is used to raise funds to develop Waqf land in Malaysia where in their research they propose a sustainable model that can overcome liquidity problems faced by Waqf institutions in developing Waqf land. 


\section{RESEARCH METHODOLOGY}

\section{Types of research}

The type of research in this study is qualitative with a literature study approach with data sources namely secondary data obtained from previous studies, and other reference sources. Literature study is the method used to collect data or sources related to the topics raised in a study obtained from various sources, journals, documentation books, internet and literature. This study tries to explain the role of zakat-system crowdfunding in zakat collection through information sources related to several programs carried out by the National Zakat Agency/ Badan Amil Zakat Nasional (BAZNAS) to improve the distribution of income in several regions in Indonesia as a case study in this study. Excavated case studies are single entities or phenomena from a particular period and activity (can be in the form of programs, events, processes, institutions or social groups), as well as collecting detailed information using various data collection procedures as long as the case occurs (Abdullah and Saebani, 2014: 71). Some of these areas include:

1. National Zakat Agency/ Badan Amil Zakat Nasional (Baznas) Cirebon City.

2. National Zakat Agency/ Badan Amil Zakat Nasional (BAZNAS) Abid Takalamingan, North Sulawesi Province (North Sulawesi).

3. National Zakat Agency/ Badan Amil Zakat Nasional (Baznas) in the Alif farmer group, Bringinsari Village, Kendal, Central Java.

4. National Zakat Agency/ Badan Amil Zakat Nasional (Baznas) of Probolinggo Regency.

\section{Data Type}

The type of data in this study uses secondary data. Secondary data is a data source that does not directly provide data to data collectors (Sugiyono, 2008: 402). This secondary data is data that is supporting the needs of primary data such as books, previous studies and various reading sources related to the Strategy Model for Increasing Zakat Potential through the Crowdfunding-Zakat System to overcome Poverty Alleviation in Indonesia.

\section{Method of collecting data}

Data collection methods used in this study use the theory triangulation technique. Data or information from one party is checked for truth by obtaining information from other sources (Abdullah and Saebani, 2014: 73). The goal is to compare information about the same things obtained from various references and literature so that there is a guarantee of the level of trust.

The benefits of triangulation theory is to increase research trust, create innovative ways of understanding phenomena, uncover unique findings, challenge or integrate theories and provide a clearer understanding of the problem. The use of various theories can help provide a better understanding when understanding the data sourced from the literature as well as the available references to serve as a reference in providing a description of the Model for Increasing the Potential of Zakat through the Crowdfunding-Zakat System to overcome Poverty Alleviation in Indonesia, based on several stages include:

1. Finding and registering all variables that need to be examined which are sourced from information containing statistical data, articles, and previous research that can be used as a reference in the discussion related to the Strategy Model for Increasing Zakat Potential through the Crowdfunding-Zakat System to overcome Poverty Alleviation in Indonesia ,

2. After the relevant information is found, the researcher then reviews and compiles library material in 
accordance with the order of importance and its relevance to the problem being studied,

3. The information material obtained is then read, recorded, arranged and rewritten,

4. Finally the process of writing research from the materials that have been collected is put together in a research concept.

\section{RESULTS AND DISCUSSION}

\section{The Role of Zakat in Poverty Alleviation in Indonesia}

In fact, the current global economic development has implications for the welfare of the country (Jaelani, 2016). Since the global financial crisis and fiscal austerity needs in many countries to deal with long-term public finances have caused sustainability concerns, the task for policymakers has been made more difficult (Jalles, 2017). Previously, Mishra (2000) stated that globalization had limited the capacity of nation-states in carrying out social protection. As a result of these implications, the limits and strength of nation-states are increasingly fading, dispersing to localities, independent organizations, civil society, supra-national bodies (such as NAFTA or the European Union), and multinational companies. In facing the ASEAN Economics Community (AEC), the economic activities carried out could not pay attention to ethical issues that could lead to fellow economic actors colliding their interests, so that this condition could create forces that could destroy other economic actors (Jaelani, 2016).

Fiscal policy is the only tool that must be addressed by policy makers to achieve a breakthrough to dampen fluctuations in the business cycle and reduce the volatility of output at the national level (Tzivinikos, 2017). Therefore, the government has a role to maintain the level of accessibility remains by using zakat regulation and other tools in the public sector (Darsono, et. al., 2017: 38). This must be utilized in order to realize the potential of zakat, which is as high as 3.40 percent of GDP. In his research, Abdullah (2015) gave suggestions related to zakat allocation policies. First, because zakat has proven to be a very effective way to help people from severe poverty (Q1), the collection and distribution of zakat must be increased. Second, because the amount of alms received by the poor medium (Q2), especially those living in rural areas, far below the amount needed for them to live worthy, then budget funds to increase the allocated amount should be increased on the agenda of the central government. Third, the old method of distributing zakat based on the provincial to national population ratio must be removed. Prediction of potential zakat BAZNAS more after the establishment which was inaugurated by the President in 2001 where BAZNAS coordinate a national fundraising charity, and there are instruments used to predict the zakat in Indonesia include: (1) The number of the Muslims; (2) Number of prosperous Muslim families; (3) Gross Domestic Product; (4) Direct surveys of the expenditure of zakat, infaq, alms of the Muslims (Azhar, et. al., 2017: 93). This will provide support for Presidential Regulation No. 18 of 2007, where Indonesia's annual economic development goals are directed at promoting economic growth in order to expand employment and reduce poverty (Fathurrahman, 2012). In addition, it can also provide support to the Ministry of Finance of the Republic of Indonesia Directorate General of Budget 2012, the target of which is to increase income evenly and provide wider access for the people to get education, health, clean water, and other basic needs.

Specifically the zakat sector facilitates the lower classes of society to be able to actively access the economy. According to Mintarti, et. al. (2012) have observed the time needed to get out of 
poverty. Without the distribution of zakat, the time needed to release the poor from the poverty line is around 7 years. Whereas the distribution of zakat is proven to shorten the time needed from 7 years to 5.1 years.

Graph 2. Estimated Time for Poverty Poverty Due to Zakat

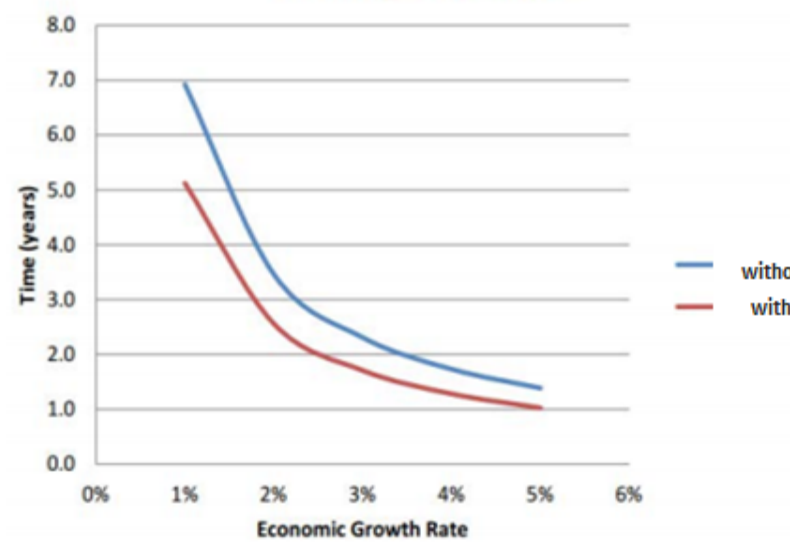

Source: Mintarti, et. al. (2012).

If you look at the role of zakat on poverty above, the strategic role of zakat for the community is as follows (Andriyanto, 2014):

\section{Capital}

According to research conducted by PIRAC (Public Interest Research and Advocacy) that the potential for zakat in Indonesia ranges from 1920 trillion per year, a sufficient capital for community development, and that number will be even greater as the Muslim awareness of zakat and fiqh ability to describe new types of business / income that are included as zakat objects.

\section{Social Justice}

The implementation of zakat raises social justice in the midst of society, in addition to the emergence of sources of zakat receipts from new types of income as well as zakat is empowered for the needs of the poor who are fulfilled by the rich in their midst.

\section{Social Equilibrium}

The social balance that is built by zakat makes the people get their share obtained from the wealth of the rich people around them, so that the social gap is not high.

\section{Social Guarantee}

The community feels guaranteed when zakat can be realized in its form, so that the poor need not worry about seeking treatment or getting education services because there is no guarantee.

5. Social Safety

With the accumulation of large zakat funds as well as development capital, it is also useful for standby funds that are ready to be used at any time, especially against unexpected events of natural disasters, fires, floods and others.

The presence of the social financial sector complements the existing financial sector and has a major impact on social satisfaction. The combination of two main sectors in the economy, namely the public and private sectors form the market production possibility frontier and produce the same level of satisfaction for the community at any point in both combinations (Darsono, et. al., 2017: 42). In this case, zakat (other than infaq, alms and endowments) is one of the social finance sectors that can increase the market production possibility frontier.

Graph 3. Community Satisfaction Curve Social \& Gov't Sector Output

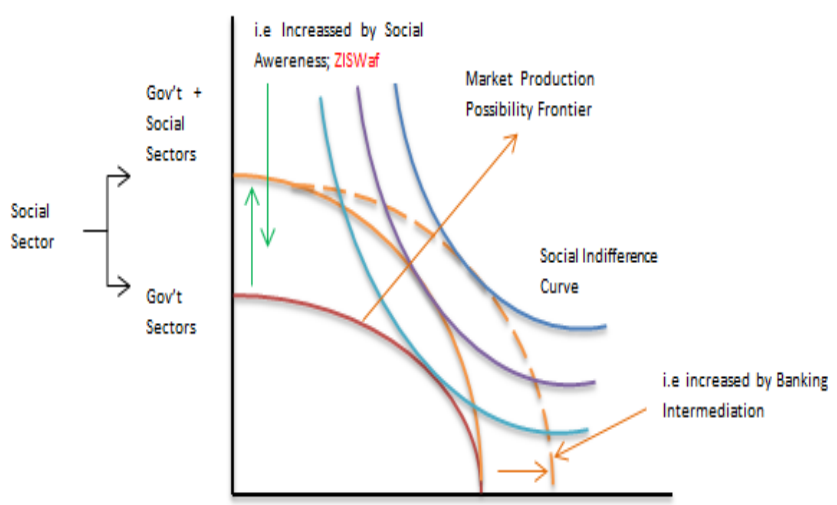

Source: Darsono, et. al. (2017: 42). 
Actually, the government has had several programs to alleviate poverty in productive communities. According to Fathurrahman (2012), one of the government's concrete steps in overcoming poverty is Program Nasional Pemberdayaan Masyarakat Mandiri (PNPM-MANDIRI). In addition, the government also carried out the Micro and Small Business Empowerment program and climate improvement by providing Kredit Usaha Rakyat (KUR). However, it is unfortunate that the capital sector held by the banking and capital market industries does not fully touch the micro sector, which mostly provides fulfillment to the needs of the community. besides, another impact is that large-scale imports also lead to a cessation of productivity in the micro sector. Suryani (as Chairman of the DPP HIPPI) said the productive small and medium sized micro business government could employ more than 107.6 million Indonesians and contribute 60.6 percent to Indonesia's GDP. He added, the strength of MSMEs in building the Indonesian economy due to its excellence in several factors namely specific focus ability, national flexibility, low cost, and speed of innovation (Nurfadilah, UMKM Maтpu Dongkrak Pertumbuhan Ekonomi, kompas.com, 10 July 2018). With the help of capital for the businesses they run, they will feel very helped (Azhar, et. al., 2017: 88). Zakat can be an alignment of existing government programs, especially to raise the potential of the poor who lack capital to be able to become entrepreneurs. Efforts to distribute income to alleviate poverty are to provide opportunities for poor productive families and communities to deal with their problems independently, which means that the government must restructure their roles, from their role as empowerment agents to empowerment facilitators. Thus the community with its micro business can help accelerate economic growth in Indonesia.
Strategy Model for Increasing Zakat Potential through the Crowdfunding-Zakat System

To achieve goals and minimize obstacles, the zakat management organization must use modern methods as a company (Syafiq, 2014). According to Andriyanto (2014) Public awareness and confidence in paying zakat through amil institutions has increased over time. The problem that is still behind the background is the distribution of zakat allocations that have not prioritized the smallest scope because of the limited access to information from the local area and the mobilization that results in the impediment of affordability. In addition, the limited access to zakat distribution is also due to the affordability of donors (muzakki) in channeling to the zakat collectors. If you look at the potential of technological development that exists today, fundraising is initially carried out more directly, between beneficiaries or institutions with donors, now it can also be done indirectly or online through the internet. In Thaker and Anwar (2018) Over the past five years, it seems the crowdfunding platform (CFP) has achieved extraordinary growth. There are a total of 1250 CFPs worldwide. Some official zakat suppliers in the country have added the option to pay tithes online, including the ones below. Crowfunding platform survey conducted by Wisudanto \& Arifin (2017) found that there were 6 crowdfunding platforms with considerable capitalization. Total funds collected from these platforms reached more than 505 billion rupiah. Total users of both investors and accessors reached 339,581 entities. 
Figure 2. Several Zakat Crowdfunding Sites in Indonesia

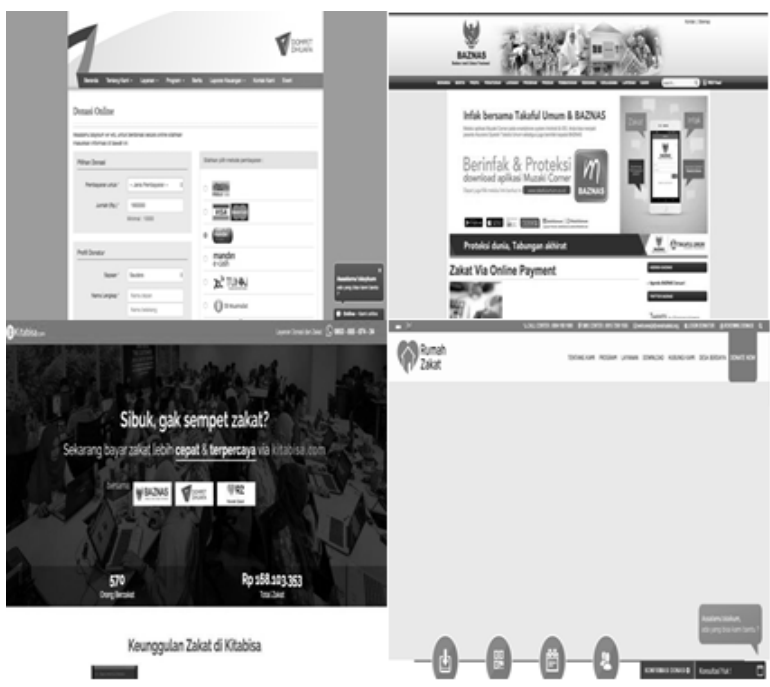

Source: Dompetdhuafa.com, puskasbaznas.com, kitabisa.com, rumahzakat.com downloaded May 23, 2018 has been processed.

Crowdfunding does not only contain external social capital but also internal social capital which both play an important role in the successful collection of funding (Arifin and Wisudanto, 2017). In Colombo et. al. (2014) crowdfunding is referred to as a loci or memory center for social relations. Citing data from a BAZNAS survey, Fuad Nasar, the Director of the Ministry of Religion's Zakat and Waqf Empowerment, said that the potential for zakat for individual wealth and income in Indonesia actually reaches Rp. 138 trillion per year. If the collection is realized in accordance with the target of 10 percent of the potential, then the next three years are projected that national zakat revenue will reach the target of Rp. 13.8 trillion per year (Agus Yulianto, Pengumpulan Zakat 2017 Naik 20 Persen, republika.co.id, January 2, 2018) With the implementation of crowdfunding zakat, zakat collecting and channeling agencies also showed their development in zakat collection and have provided several programs to improve income distribution in several regions in Indonesia which show the potential and positive impact in income distribution, including: a. The National Zakat Amil Agency (Baznas) of Cirebon City targets the collection of zakat this year to reach Rp. 5 billion. Even though it increased compared to last year, the actual potential of zakat is even greater. The Head of Baznas Cirebon City, Dwi Budi Novianto revealed during the Seminar on Inheritance of Capital Loans and Baznas Scholarships in Cirebon City, Tuesday (20/2), the potential of zakat in the City of Cirebon is actually very large. He estimates, the figure is in the range of Rp. 10 billion (Lilis Sri Handayani/ Hazliansyah, Baznas Kota Cirebon Targetkan Pengumpulan Zakat Rp 5 Miliar, republika.co.id, February 20, 2018).

b. Chairman of the National Zakat Agency (BAZNAS) Abid Takalamingan said in North Sulawesi Province (Sulut) it was estimated that the potential for zakat could reach Rp. 60 billion in a year (Ani Nursalikah, Potensi Zakat Sulut Rp 60 Miliar, republika.co.id, March 29 2018).

c. The National Zakat Agency (Baznas) is running a farm development program to villages where the community has the potential to be fostered as farmers. The program has been running for about a year and received a pretty good response. One of the results of the assistance of Baznas is the Alif farmer group, Bringinsari Village, Kendal, Central Java. Chairman of the Alif farmer group, Bukhor said, when Baznas came to provide assistance and guidance, the conditions of the local community were included in the criteria for pre-prosperity (Rahmat Fajar/ Agus Yulianto, Program Pemberdayaan Peternak Baznas Direspons Warga, republika.co.id, August 17, 2017).

d. The National Zakat Agency (Baznas) of Probolinggo Regency is rolling out a community economic empowerment program. No half-hearted, the budget prepared for 5 (five) districts reaches 
Rp. 100 million. Where each subdistrict gets an allocation of Rp. 20 million. The five regions were chosen because the poverty rate is quite high and in remote areas. Especially in Pakuniran Subdistrict, because there has already been a Zakat Management Unit (UPZ) that handles agricultural zakat and zakat mal. According to Muzammil, the community's economic empowerment program aims to help at least 1 person who cannot afford it. The hope is that this program will run in a rolling manner so that the benefits can be felt by all disadvantaged communities (Syamsul Akbar, Baznas Gulirkan Program Pemberdayaan Ekonomi Umat, www.probolinggokab.go.id, May 26, 2017).

In the distribution of zakat through the system of mutual funds, the system can have a positive impact on the acceleration in increasing the income distribution of the poor. This helps to achieve efficient allocation of resources in the economy (Thaker and Anwar, 2018). Based on modern management as intended in Law Number 38 of 1999 concerning the management of zakat, which was then amended by Law No. 23 of 2011 concerning the Management of Zakat, is intended so that zakat is able to make a real contribution to improving the welfare of the people. Syafiq (2014) explains, in fundraising strategies, and the distribution must follow modern management and strategy as a company in achieving its target.

Therefore, there is a need for cooperation between the government and zakat management so that income distribution continues to develop. As the government functions as a fiscal policy as an instrument in realizing economic objectives, namely as an income policy. In Islam fiscal policy adheres to the steps taken by the Prophet Muhammad SAW, especially in increasing rational income and the level of work participation. The Messenger of Allah carried out the policy of airing the Muhajirin and Ansar which caused the distribution of income from the Ansar to Muhajirin which had implications for the increase in total demand in Medina (Yuniarti, 2016: 225). The zakat management model intended is as follows.

Figure 3. Zakat Management Model through the Crowdfinding-Zakat System Model

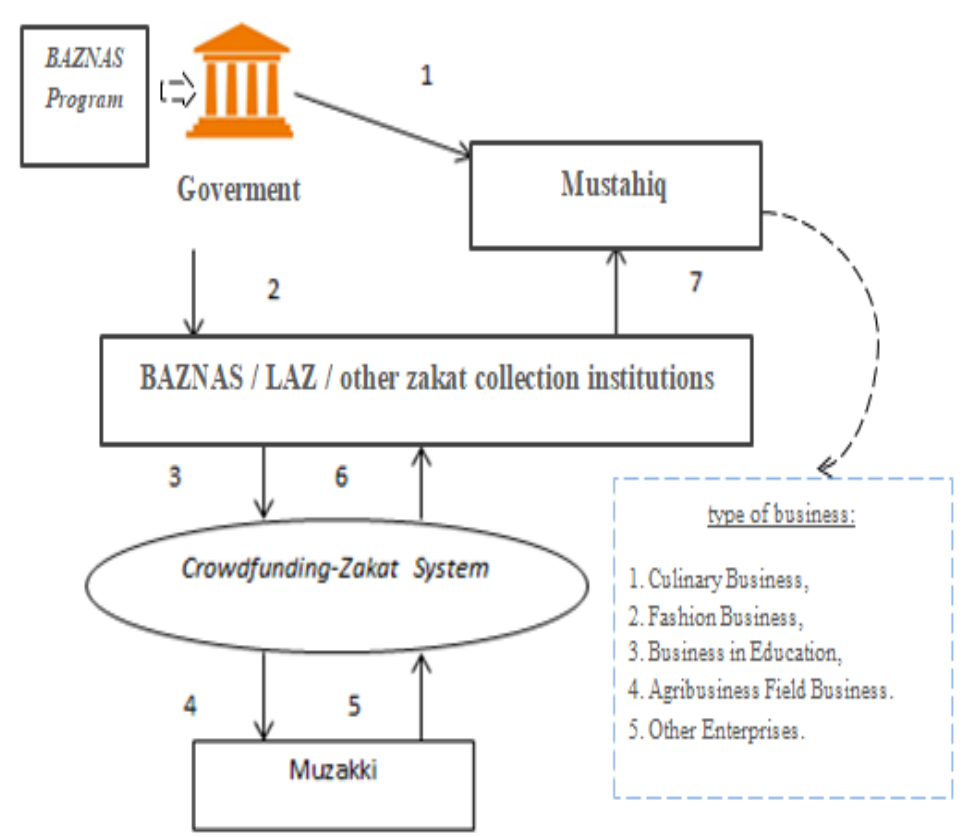

From the above model (figure 3), crowdfunding is intended as a donation collection system (crowdfunding donations). The crowdfunding platform acts as an intermediary institution that brings together investors and backers (Valanciene \& Jegeleviciute, 2014). In step 1 , the Government is tasked with monitoring to see the level of welfare of local communities in order to survey the economic conditions in the area. Step 2, BAZNAS/ LAZ/ other zakat collecting institutions based on the provisions and information from the order to verify the community (mustahiq) who need financial assistance for development or are looking to start their business. step 3, BAZNAS/ LAZ/ other zakat collecting institutions through the crowdfunding-zakat platform provides services for collecting zakat on the muzakki. Step 4 picks up the muzakki who 
want to donate their zakat funds through advertising on the crowdfunding-zakat platform. Step 5, Collect funds from muzakki who want to distribute zakat by the manager. Step 6, the zakat donations received are directed to BAZNAS/ LAZ/ other zakat collecting institutions that manage the zakat-crowdfunding site. On step 7, BAZNAS/ LAZ/ other zakat collecting institutions that have the authority to allocate zakat to mustahiq who have fulfilled verification in the implementation of BAZNAS programs.

This will facilitate the mustahiq to develop their potential and fulfill the need for venture capital through these income distribution programs. Social capital refers to the collective value of all social networks and trends arising from these networks to norms of reciprocity (al-Faizin and Akbar, 2018: 191). The Crowdfunding-zakat system can provide benefits in bridging donors with people who need more efficient funds in the collection of zakat will increase.

\section{CONCLUSION}

Over the past five years, it seems the crowdfunding platform (CFP) has achieved extraordinary growth. There are a total of 1250 CFPs worldwide. In the distribution of zakat through the system of mutual funds, the system can have a positive impact on the acceleration in increasing the income distribution of the poor. Fuad Nasar, the Director of the Ministry of Religion's Zakat and Waqf Empowerment, said that the potential for zakat for individual wealth and income in Indonesia actually reaches $\mathrm{Rp}$. 138 trillion per year. The CrowdfindingZakat system provides convenience in the collection of zakat funds from the wider community in line with several regions in Indonesia which show the potential and positive impact in income distribution, including: a. The National Zakat Amil Agency/ Badan Amil Zakat Nasional (Baznas) of Cirebon City targets the collection of zakat this year to reach Rp. 5 billion.

b. Chairman of the National Zakat Agency/ Badan Amil Zakat Nasional (BAZNAS) Abid Takalamingan said in North Sulawesi Province (Sulut) it was estimated that the potential for zakat could reach Rp. 60 billion a year.

c. Baznas look for villages whose communities have the potential to be fostered as farmers. One of the results of the assistance of Baznas is the Alif farmer group, Bringinsari Village, Kendal, Central Java.

d. The National Zakat Agency/ Badan Amil Zakat Nasional (Baznas) of Probolinggo Regency is rolling out a community economic empowerment program. The budget prepared for 5 (five) districts reaches Rp. 100 million. Where each sub-district gets an allocation of Rp. 20 million.

The potential of zakat collection which has implications for its allocation, also needs support from other factors, including understanding the people who are obliged to pay zakat (Muzakki) must also be increased, because it has a link in influencing the amount of zakat funds collected by zakat institutions. In addition, education needs to be given to the public regarding the obligation to pay zakat, so that the program of income distribution and poverty alleviation through the potential of zakat can continue to be carried out. And, in order for the poverty alleviation program through crowdfunding-zakat system to be implemented properly, and empowerment of the productive community can be carried out, assistance can be made so that it can be directed and maintained its sustainability level, especially for capital assistance programs through the supervision team from BAZNAS. In addition, there is monitoring that is responsible for the program, so that business development can be monitored optimally. 


\section{REFERENCES}

Abdullah, Naziruddin et. al (2015). The effectiveness of zakat in alleviating poverty and inequalities, Humanomics, Vol. 31 Iss 3 pp. 314 $-329$.

Abdullah, Prof. Dr. H. Boedi M.Ag., Drs. Beni Ahad Saebani, M.Si (2014). Metode Penelitian Ekonomi Islam (Muamalah), Bandung: CV Pustaka Setia.

Ahmed, Bilqis Ololade, Fuadah Johari, Kalsom Abdul Wahab (2017). Identifying the poor and the needy among the beneficiaries of zakat: a need for zakat-based poverty threshold in Nigeria, International Journal of Social Economics, Vol. 44 Iss 4 pp. -, http://dx.doi.org/10.1108/IJSE-092015-0234.

Akbar, Syamsul, Baznas Gulirkan Program Pemberdayaan Ekonomi Umat, www.probolinggokab.go.id, $26 \mathrm{Mei}$ 2017.

Al-Faizin, Abdul Wahid dan Nashr Akbar (2018). Tafsir Ekonomi Kontemporer: Menggali Teori Ekonomi dari Ayat-Ayat al-Qur'an, Jakarta: Gema Insani.

Andriyanto, Irsad (2014). Pemberdayaan Zakat Dalam Meningkatkan Kesejahteraan Umat, Jurnal Zakat dan Wakaf, Vol. 1, No. 2, Desember 2014.

Arifin, Salahuddin Rijal, dan Wisudanto (2017). Crowdfunding Sebagai Alternatif Pembiayaan Pembangunan Infrastruktur, University Network for Indonesia Infrastructure Development (UNIID 2017), Palembang, 19-20 September 2017.

Azhar, Aziz Harry, et. al. (2017). Zakat dan Pemberdayaan, Surabaya: Airlangga University Press.

BAZNAS (2017). 2017 Indonesia Zakat Outlook, Jakarta: Center of
Strategic Studies The Indonesian Nasional Zakat Board (BAZNAS).

Berita Resmi Statistik No. 05/01/Th. XXI, 2 Januari 2018, Profil Kemiskinan di Indonesia September 2017, www.bps.go.id diunduh 15 Mei 2018.

Colombo, M. G., Franzoni, C., \& RossiLamastra, C. (2015). Internal social capital and the attraction of early contributions in crowdfunding. Entrepreneurship Theory and Practice, 39(1), 75-100.

Darsono, et. al. (2017). Masa Depan Keuangan Syariah Indonesia, Jakarta: Tazkia Publishing.

Dompetdhuafa.com, downloaded May 23, 2018.

Fathurrahman, Ayief (2012), Kebijakan Fiskal Indonesia Dalam Perspektif Ekonomi Islam: Studi Kasuh Dalam Mengentaskan Kemiskinan, Jurnal Ekonomi dan Studi Pembangunan, Volume 13, Nomor 1, April 2012, hlm.72-82.

Fajar, Rahmat, Agus Yulianto, Program Pemberdayaan Peternak Baznas Direspons Warga, republika.co.id, 17 August 2017.

Handayani, Lilis Sri, Hazliansyah, Baznas Kota Cirebon Targetkan Pengumpulan Zakat Rp 5 Miliar, republika.co.id, 20 Februari 2018.

Hidayat, Taufik (2017). Konsep Pendistribusian Kekayaan Menurut Al-Qur'an, Al-Falah: Journal of Islamic Economics, Vol. 2, No. 1.

Jaelani, Aan (2015). Pengelolaan Keuangan Publik di Indonesia: Tinjauan Keuangan Publik Islam, dipresentasikan pada International Conference on Islamic Economics and Business (ICONIES) Faculty of Economics, Maulana Malik Ibrahim State Islamic University Malang, Paper No. 69525, 2 - 3, Nopember 2015.

Jalles, Joao Tovar (2017). How do Fiscal Adjustments change the Income Distribution in Emerging Market 
Economies?, International Journal of Emerging Markets, Vol. 12 Issue: 2,pp. -, doi: 10.1108/IJoEM-102015-0219.

K., Amiruddin (2015). Model-Model Pengelolaan Zakat di Dunia Muslim, AHKAM, Volume 3, Nomor 1, Juli 2015: 139-166.

Kitabisa.com, downloaded May 23, 2018.

Mintarti, N., Beik, I. S., Tanjung, H., Haryono, A. R., Tsani, T., Kasirin, U. (2012). Indonesia Zakat and Development Report 2012. Ciputat: IMZ.

Mishra, Ramesh (2000). Globalization and the Welfare State, London: McMillan.

Mustafa, Murtala Oladimeji Abioye, Muslim Har Sani Mohamad, Muhammad Akhyar Adnan (2013). Antecedents of zakat payers' trust in an emerging zakat sector: an exploratory study, Journal of Islamic Accounting and Business Research, Vol. 4 Iss 1 pp. $4-25$, http://dx.doi.org/10.1108/17590811 311314267.

Nurfadilah, Putri Syifa, UMKM Mampu Dongkrak Pertumbuhan Ekonomi, kompas.com, 10 Juli 2018.

Nursalikah, Ani, Potensi Zakat Sulut Rp 60 Miliar, republika.co.id, 29 Maret 2018.

Obaidullah, Mohammed (2016). Revisiting Estimation Methods of Business Zakat and Related Tax Incentives, Journal of Islamic Accounting and Business Research, Vol. 7 Iss 4 pp.

Pusat Pengkajian dan Pengembangan Ekonomi Islam (P3EI) (2014). Ekonomi Islam, Jakarta: Rajawali Pers.

Puska.baznas.com, downloaded May 23, 2018.

Rumahzakat.com, downloaded May 23, 2018.

Sugiyono, (2008). Metode Penelitian Kunatitatif Kualitatif dan R\&D. Bandung Alfabeta.
Syafiq, Ahmad (2014). Prospek Zakat dalam Perekonomian Modern, ZISWAF, Vol. 1, No. 1, Juni 2014.

Thaker, Mohamed Asmy Bin Mohd Thas, Anwar Allah Pitchay (2018). Developing waqaf land through crowdfunding-waqaf model (CWM): the case of Malaysia, Journal of Islamic Accounting and Business Research, https://doi.org/10.1108/JIABR-052016-0062.

Thalib, Hamidy, et. al. (2017). Model Pengelola Zakat untuk Mengatasi Kemiskinan di Kota Bima, Jurnal Kajian Ekonomi Islam, Volume 2, Nomor 1, Januari-Juni 2017.

Tim Divisi Kepatuhan dan Kajian Dampak LAZ al-Azhar (2017). Panduan Zakat Lembaga Amil Zakat alAzhar, Jakarta: Yayasan Pesantren Islam al Azhar, Masjid Agung alAzhar.

Tzivinikos, Stephanos Papadamou Trifon (2017). The macroeconomic effects of fiscal consolidation policies in Greece, Journal of Financial Economic Policy, Vol. 9 Iss 1 pp. -

Valanciene, L., \& Jegeleviciute, S. (2014). Crowdfunding for creating value: stakeholder approach. ProcediaSocial and Behavioral Sciences, 156, 599-604.

Wisudanto., \& Arifin, S.R. (2017). Crowdfunding New Paradigm for Financing : Operational Pattern of Crowdfunding in Indonesia. "Global Conference on Business, Management, and Entrepreneurship. Surabaya, Agustus."

Yulianto, Agus, Pengumpulan Zakat 2017 Naik 20 Persen, republika.co.id, 2 Januari 2018.

Yuniarti, Vinna Sri (2016). Ekonomi Makro Syariah, Band ung: Pustaka Setia. 


\author{
Ajeng Sonial Manara \\ Airlangga University \\ Indonesia \\ Ajengmanara93@gmail.com \\ Arif Rachman Eka Permata \\ Trunojoyo Madura University \\ Indonesia \\ Arifrachman2594@gmail.com \\ R. Gatot Heru Pranjoto \\ Trunojoyo Madura University \\ Indonesia \\ Gatot_pranjoto@yahoo.com
}


